\title{
Correction to: Alpha-Synuclein, cyclooxygenase-2 and prostaglandins-EP2 receptors as neuroinflammatory biomarkers of autism spectrum disorders: Use of combined ROC curves to increase their diagnostic values
}

\begin{abstract}
Afaf El-Ansary ${ }^{1,2^{*}}$, Manan Alhakbany ${ }^{3}$, Abeer Aldbass ${ }^{4}$, Hanan Qasem ${ }^{5}$, Sarah Al-Mazidi ${ }^{5}$, Ramesa Shafi Bhat ${ }^{5}$ and Laila Al-Ayadhi, ${ }^{2,3}$
\end{abstract}

Correction to: Lipids Health Dis 20, 155 (2021). https://doi.org/10.1186/s12944-021-01578-7

Following publication of the original article [1], the authors noticed that the funding statement is incorrect and needs amendment to match the acknowledgement. Please see below correct funding statement.

\section{Acknowledgements}

The authors wish to acknowledge the National Plan for Science Technology and Innovation (MAARIFAH), King Abdulaziz City for Science and Technology, Kingdom of Saudi Arabia (award number:08-MED 510-02).

\section{Funding}

This work was funded through the National Plan for Science Technology and Innovation (MAARIFAH), King Abdulaziz City for Science and Technology, Kingdom of Saudi Arabia (award number:08-MED 510-02).

The original article has been corrected.

\section{Author details}

${ }^{1}$ Central Laboratory, Female Center for Medical Studies and Scientific Section, King Saud University, P. O Box 22452, KSA, Riyadh 11495, Saudi Arabia.

${ }^{2}$ Autism Research and Treatment Center, Riyadh, Saudi Arabia. ${ }^{3}$ Department of Physiology, Faculty of Medicine, King Saud University, Riyadh, Saudi Arabia. ${ }^{4}$ Biochemistry Department, College of Science, King Saud University, Riyadh, Saudi Arabia. ${ }^{5}$ Department of Physiology, College of Medicine, Al-Imam Mohammed Bin Saud Islamic University, Riyadh, Saudi Arabia.

Published online: 28 November 2021

\section{Reference}

1. El-Ansary A, Alhakbany M, Aldbass A, et al. Alpha-Synuclein, cyclooxygenase2 and prostaglandins-EP2 receptors as neuroinflammatory biomarkers of autism spectrum disorders: use of combined ROC curves to increase their diagnostic values. Lipids Health Dis. 2021;20(1):155. https://doi.org/10.1186/ s12944-021-01578-7.

The original article can be found online at https://doi.org/10.1186/s12944021-01578-7.

*Correspondence: afafkelansary@gmail.com

${ }^{1}$ Central Laboratory, Female Center for Medical Studies and Scientific Section, King Saud University, P. O Box 22452, KSA, Riyadh 11495, Saudi Arabia

${ }^{2}$ Autism Research and Treatment Center, Riyadh, Saudi Arabia

Full list of author information is available at the end of the article

(c) The Author(s). 2021 Open Access This article is licensed under a Creative Commons Attribution 4.0 International License, which permits use, sharing, adaptation, distribution and reproduction in any medium or format, as long as you give appropriate credit to the original author(s) and the source, provide a link to the Creative Commons licence, and indicate if changes were made. The images or other third party material in this article are included in the article's Creative Commons licence, unless indicated otherwise in a credit line to the material. If material is not included in the article's Creative Commons licence and your intended use is not permitted by statutory regulation or exceeds the permitted use, you will need to obtain permission directly from the copyright holder. To view a copy of this licence, visit http://creativecommons.org/licenses/by/4.0/ The Creative Commons Public Domain Dedication waiver (http://creativecommons.org/publicdomain/zero/1.0/) applies to the data made available in this article, unless otherwise stated in a credit line to the data. 